\title{
KOMUNIKASI UNTUK PERUBAHAN SOSIAL BERBASIS PEMBERDAYAAN MASYARAKAT SIPIL DI PONDOK PESANTREN NURUL HAROMAIN
}

\author{
Anang Sujoko, Akhmad Muwafik Saleh, Fariza Yuniar Rakhmawati, \\ Nilam Wardasari, Misbahuddin Azzuhri \\ Universitas Brawijaya \\ anangsujoko@ub.ac.id \\ muwafik@ub.ac.id \\ farizayuniar@gmail.com \\ nilamwardasari@gmail.com \\ misbah@ub.ac.id
}

\begin{abstract}
Islamic boarding schools become a great asset of the nation. Its existence has never subsided to continue to be explored as a source of great value. On the other hand the internal dynamics of the pesantren in responding to important times continue to be studied. This study aims to identify the problems and potential of Nurul Haromain Islamic Boarding School Malang Regency related to entrepreneurial management in managing the Q-Zulal water business. The design of Participation Action Research research is used as one of the qualitative methodologies. The results of this study indicate that the limitations of production management and human resources in managing the Q-Zulal water business as a basis for consideration in formulating planning and implementation of civil society-based empowerment programs. To overcome this problem, a group discussion, workshop and mentoring forum was conducted with a focus on production management and management resources. Through this activity, outputs are generated in the form of Standard Operating Procedures and structuring of management resources. Through this scheme, this research is not only a means of seeing the existing reality, but also as a part of communication for social change in empowering pesantren as agents of development.
\end{abstract}


Keywords: Communication, Social Change, Islamic Boarding School, Participatory Action Research.

\begin{abstract}
Abstrak
Pesantren menjadi aset besar bangsa. Eksistensinya tidak pernah surut untuk terus digali sebagai sumber nilai adiluhung. Di sisi lain dinamika internal pesantren dalam merespon zaman penting untuk terus dikaji.Penelitian ini bertujuan untuk mengidentifikasi permasalah dan potensi Pondok Pesantren Nurul Haromain Kabupaten Malang berkaitan dengan manajemen kewirausahaan dalam mengelola usaha air Q-Zulal. Desain penelitian Participation Action Research digunakan sebagai salah satu metodologi kualitatif. Hasil penelitian ini menunjukkan bahwa keterbatasan manajemen produksi dan sumber daya manusia dalam mengelola usaha air Q-Zulal sebagai dasar pertimbangan dalam merumuskan perencanaan dan implementasi program pemberdayaan berbasis masyarakat sipil. Untuk mengatasi persoalan tersebut, dilakukan forum group discussion, workshop dan pendampingan dengan fokus manajemen produksi dan sumber daya pengelola. Melalui aktivitas ini, dihasilkan luaran berupa Standar Operasional Prosedur dan strukturisasi sumber daya pengelola. Melalui skema ini, penelitian ini tidak hanya sebagai sarana melihat realitas yang ada, namun juga menjadi bagian komunikasi untuk perubahan sosial dalam memberdayakan pesantren sebagai agen pembangunan.
\end{abstract}

Kata Kunci: Komunikasi, Perubahan Sosial, Pesantren, Participatory Action Research. 


\section{A. Pendahuluan}

Tingkat perekonomian di Indonesia masih berada di bawah standarjika mengacu pada ketentuan BankDunia.BankDuniamenetapkan bahwa suatu negara dikatakan masuk dalam kluster perekonomian yang baikjika jumlah penduduk yang berwirausaha minimal 4 persen. Sementara di Indonesia hanya mencapai 3,3 persen, bahkan relatif tertinggal daripada Malaysia yang mencapai 5 persen dan Singapura berada di angka 7 persen. ${ }^{1}$

Di satu sisi Indonesia memiliki persoalan, di sisi lain juga memiliki potensiyangbesarterutamaberkaitan dengan upaya peningkatan jumlah wirausaha. Salah satu sektor yang berpotensi untuk dikembangkan adalah pesantren. Jumlah pesantren dari tahun ke tahun mengalami peningkatan. Data tahun 2016 dari Bagian Data, Sistem Informasi, dan Hubungan Masyarakat Sekretariat Direktorat Jenderal Pendidikan Islam Kementerian Agama merilis ada sekitar 28.194 pesantren dengan hampir 5 juta santri yang tersebar baik di tingkat kota maupun desa.

1 Josephus Primus, "Apa jadinya Indonesia Tanpa Wirausaha?", diakses dari https://edukasi. kompas.com/read/2018/03/23/08450051/ apa-jadinya-indonesia-tanpa-wirausaha-, pada tanggal 13 November 2018 pukul 20.00.
Namun, potensi ini masih belum dioptimalkan sebagai alternatif mengatasi persoalan yang ada termasuk dengan mencetak wirausaha-wirausaha santri.

Keberadaan pesantren yang berada di desa seharusnya dapat menjadi agen perubahan dalam rangka melakukan agenda pembangunan. Salah satu desa yang terdapat pesantren adalah Desa Ngroto, Kecamatan Pujon, Kabupaten Malang. Secara lebih terperinci jika dengan mengacu status desa berdasarkan Indeks Desa Membangun (IDM), Desa Ngroto masihberadadileveldesaberkembang dari lima status yang telah ditetapkan sebagai standar nasional, mulai dari desa sangat tertinggal, desa tertinggal, desa berkembang, desa maju sampai menuju desa mandiri. Angka persentase IDM Desa Ngroto masih berada di level 0,6464, sehingga masuk dalam kategori desa berkembang. Keberadaan pesantren dalam konteks ini masih belum ditempatkan sebagai peluang untuk mengarahkan menjadi desa yang mandiri dengan minimal IDM harus berada di angka lebih dari 0,815.

Pesantren yang terdapat di Desa Ngroto adalah Pesantren Nurul Haromain. Pesantren ini didirikan sejak tahun 1987 oleh Sayyid 
Muhammad Alawy Al-Maliki yang dibuka dan dimulai penyelenggaraan pendidikannya pada tahun $1991 \mathrm{M}$. Sayyid Muhammad Alawy Al-Maliki adalah seorang ulama terkemuka dari Mekkah yang merupakan guru dari pengasuh Pesantren Nurul Haromain saat ini-K.H. Muhammad Ihya Ulumuddin. Berbeda dari pesantren pada umumnya, santri di pesantren ini bukan merupakan orang yang pemula untuk belajar mengaji namun orang-orang terpilih yang sudah mempunyai pengalaman menjadi santri sebelumnya. Hal ini merupakan potensi yang sangat strategis dalam upaya pengembangan sumber daya manusia baik dalam aspek keilmuan di satu sisi dan potensi besar terkait jaringan kader dakwah ke beberapa daerah yang telah tersebar.

Sejumlah permasalahan dihadapi Pesantren Nurul Haromain, seperti capacity building sumber daya santri, manajemen pengelolaan internal dan enterpreneurship skill santri yang masih terbatas. Upaya pemberdayaan masyarakat berbasis kewirausahaan santri menjadi poin penting. Melalui upaya pemberdayaan pesantren dapat menguatkan posisi pesantren sebagai elemen penting pembangunan meskipun tidak masuk dalam struktur birokrasi secara formal.

Upaya pemberdayaaan pesantren dapat ditempatkan dalam kajian komunikasi untuk perubahan sosial. Pesantren dapat menjadi aktor sekaligus media perubahan sosial itu sendiri. Dibeberapa negara, teori dan konsepkomunikasiuntukperubahan sosial telah dimanfaatkan untuk meningkatkan kualitas masyarakat dalam merespon perubahan terutama dari era konvensional ke arah teknologi digital. Praktikpraktik pemberdayaan masyarakat berlangsung untuk menguatkan kompetensi hidup masyarakatnya. Komunikasi untuk perubahan sosial juga dapat dimaknai sebagai upaya menghubungkan aktor-aktor strategis untuk bersinergi dalam mendukung terjadinya perubahan sosial.

Kaitan antara komunikasi dan perubahan sosial sempat dikaji oleh banyak ilmuwan. Meskipun tidak sedikit juga yang melontarkan kritik terhadappenghubungan dua konteks ini. Kritik yang dilontarkan 'tidak sesuai jalur'.2 Menurutnya, ranah teoritis ilmu komunikasi memang seharusnya mampu menciptakan

2 Pradip Ninan Thomas, Communication for Social Change, Making Theory Count(Nordicom Review,Vol 36, 2015), 72. 
perubahan sosial dengan caracara yang tepat. Ia mengatakan bahwa para pengkritik kehilangan esensi dari sebuah teori, bahkan ia menyebutnya sebagai 'fetishism of practice'. Ia mencontohkan sebuah peristiwa di India, yaitu Gerakan RTI yang berangkat dari sebuah cara komunikasi yang tepat lalu bisa mengubah persepsi masyarakat India terhadap gerakan tersebut. Tujuan utama dari berkomunikasi yang tepat ialah didengar oleh orang lain. Apa yang dilakukan Geraka RTI untuk terus 'bersuara' menyadarkan orang lain terhadap substansi gerakan tersebut mengenai transparansi dan akuntabilitas. Oleh karenanya, gerakan ini meluas dengan skala nasional.

\section{B. KomunikasiUntukPerubahan Sosial}

Komunikasi untuk perubahan sosial atau dikenal dengan Communication for Social Change atau dikenal dengan CSC merupakan konsepsiuntukmelakukan eksplorasi terkait beragam cara, informasi, proses komunikasi maupun media yang dapat dimanfaatkan untuk menghasilkan perubahan sikap, perilaku dan pengetahuan pada individu dan komunitas. ${ }^{3}$. Lebih lanjut diketahui bahwa CSC dikembangkan sejak 2006 dan telah tercatat memberikan kontribusi yang relatif signifikan baik dari segi teoritis maupun praktis dalam memengaruhi pembangunan berkelanjutan. Praktik komunikasi untuk perubahan sosial terjadi di sejumlah negara, di abad 21 ini penggunaan teknologi informasi dan komunikasi juga menjadi catatan penting sebagai media perubahan sosial itu sendiri.

Sejumlah figur telah memotret interelasi antara komunikasi dengan perubahan sosial, seperi Hedebro, McClelland, Lerner, Schramm, Rogers, Tehranian dan Servaes. Konsep penting yang cukup klasik dirumuskan Hedebro adalah bahwa perubahan sosial selalu melibatkan praktik komunikasi. Sementara dalam perkembangannya, menurut Tehranian pada periode pasca perang, teori komunikasi dan perubahan sosial didominasi dua aliran besar yakni liberal dan Marxis ${ }^{4}$. Pandangan liberal mengarah

\footnotetext{
3 Pradip Ninan Thomas, Exposing Injustice: ICTS \& Social Change(Queensland: The University of Queensland Australia, 2013).

4 Majid Tehranian, Communication and Theories of Social Change: A Communitarian
} 
pada paradigma modernisasi yang cenderung basis analisisnya berhubungan dengan pengembangan proses mental dan mengambil simpulan yang parsial untuk kepentingan pasar serta penetrasi perusahaan transnasional atas ekonomi negara-negara dunia ketiga ${ }^{5}$. Sementara Marxis mengarah pada materialisme historis yang mencoba mengkritisi praktik modernisasi yang dianggap pro terhadap kepentingan kapitalis yang membuat adanya mindset kebergantungan dari pihak-pihak yang lemah atas elit ${ }^{6}$.

Secara lebih terperinci konteks kajian komunikasi dan perubahan sosial dibagi ke dalam empat paradigma, antara lain paradigma mekanis, organik, sibernetik dan linguistik ${ }^{7}$. Pertama, paradigma mekanis menonjolkan perubahan sosial dilakukan dengan mengedepankan struktur mekanis melalui instrumentasi yang melibatkan rekayasa sosial dan manipulasi untuk memenuhi efisiensi. Kedua, paradigma organik melibatkan proses difusi budaya dan sosial untuk menginduksi perubahan

Perspective(Asian Journal of Communication, 2009), 1.

5 Ibid, 3.

6 Ibid, 1.

7 Ibid, 12. secara bertahap dari yang sederhana menuju yang kompleks. Ketiga, paradigma sibernetik mengarah pada upaya rasionalisasi melalui pengawasan sosial dan pemberian umpan balik dalam suatu sistem yang terikat dalam rangka memperoleh efisiensi yang tinggi. Keempat, paradigma linguistik memandang perubahan sosial dilakukan melalui agensi dan strukturasi sebagai upaya emansipasi sumber daya manusia dari kontrol sistem dan kuasa.

Contoh yang diberikan oleh Thomas pada Gerakan RTI sesuai dengan teori Social Marketing milik Kotler dan Zaltman. ${ }^{8}$ Mereka meletakkan pondasi konseptual yang kokoh untuk social marketing. Kotler dan Zaltman berpijak pada fenomena ketika teknik pemasaran berhasil memengaruhi orang untuk membeli dan menggunakan produk. Mereka melihat hal ini dapat diterapkan juga ke ranah sosial. Beragam permasalahan sosial yang ada kadangkala menuntut perubahan pola perilaku individu atau kelompok. Namun, tuntutan tersebut tidak serta langsung berhasil. Dalam hal ini, Kotler dan Zaltman menciptakan teknik-

8 Marwan M. Kraidy, Social Change and the Media(Encyclopedia of Communication andInformation, Vol 3 (1), 2002), 934. 
teknik komunikasi pemasaran untuk perubahan sosial. Untuk menyukseskan perubahan sosial tersebut, konsep social marketing akan menyasar dua kelompok besar. Pertama, individu atau kelompok yang bisa mendapat keuntungan dengan perubahan perilaku. Kedua, pembuat kebijakan yang mampu membuat regulasi terkait dengan upaya mengubah perilaku masyarakat dalam cakupan luas. Dalam konteks social marketing, perubahan sosial bisa terjadi apabila, beroritentasi pada masyarakat, didasarkan pada pertukaran nilai dan ide sosial antara penyelenggara kampanye dan kelompok sasaran, serta komunikasi terus disuarakan dalam jangka waktu yang panjang.

\section{Manajemen Pengelolaan Produksi Usaha}

Kemampuan suatu negara untuk memproduksi sebagian besar produk yang dikonsumsi secara lokal merupakan salah satu faktor yang menandai perkembangan suatu negara. ${ }^{9}$ Dalam penelitiannya, manajemen produksi memainkan peranan penting agar produk yang dihasilkan sesuai dengan

9 Godfrey C. Onwubolu dkk,Production Management Issues in Developing Nations. (Production Planning and Control, Vol10 (2), 1999),110. kebutuhan pelanggan. Perusahaan harus mampu menciptakan nilainilai dari produk yang mereka hasilkan. Nilai suatu produk dapat dikatakan berhasil tersampaikan ke konsumen, apabila konsumen bersedia membayar harga produk tersebut. Oleh karena itu menurut Onwubolu dkk, melalui manajemen produksi yang baik, perusahaan dapat memaksimalkan keuntungan tanpa harus mengorbankan manfaat yang bisa diraih pelanggan.

Untuk bisa memproduksi suatu produk, perusahaan tidak bisa sembarangan, ada strategi dan taktik khusus yang harus direncanakan baik-baik supaya kualitas dan kuantitas produk sesuai dengan yang diharapkan. Strategi dan taktik itu di dalam dunia bisnis dikenal dengan istilah Manajemen Pengelolaan Produksi. Manajemen Pengelolaan Produksi berarti proses perencanaan, pengorganisasian, pengarahan, dan pengontrolan terhadap segala aktivitas produksi. ${ }^{10}$ Daneshjo menjelaskan tujuan utama dari manajemen produksi ini adalah memproduksi barang atau jasa dengan kualitas dan kuantitas yang sesuai, tepat waktu, serta dengan biaya produksi yang kecil.

10 Naqib Daneshjo, Porduction Management Systems(Transfer inováciț, Vol28, 2013), 36. 
Pada era kontemporer seperti ini, majanemen produksi tidak bisa selamanya bertahan menggunakan satu metode tertentu. Dalam hal ini, perubahan proses bisnis atau manajemen produksi sangat diperlukan. Tujuannya selain bisa menjawabtantanganzamansekaligus untuk meningkatkan efektivitas dan produktivitas perusahaan . ${ }^{11}$ Penelitian tersebut menjelaskan bahwa perusahaan yang tidak mau mengubah manajemen produksinya sewaktu-waktu dapat tertinggal. Oleh karena itu, metode terbaru sangat diperlukan oleh perusahaan supaya bisa mempertahankan nilai yang dimiliki oleh produknya. Merangkum lima macam metode dan model manajemen produksi yang digunakan perusahaan pada era kontemporer untuk mempertahankan produksinya: (1) Balance Scorecard, (2)Benchmarking, (3) Lean Production, (4) Total Quality Management, dan (5) Business Process Re-engineering. ${ }^{12}$

Business Process Re-engineering (BPR) merupakan metode yang digunakan oleh perusahaan yang bertujuan merancang ulang

11 Nedelljko Śtefanić., Ozana Kriżan., \&Ivo Cala,Models and Methods of Production Management(Strojarstvo, Vol 3, 2008), 177.

12 Ibid. konsep bisnisnya secara radikal atau menyeluruh ${ }^{13}$. Dijelaskan dalam penelitian tersebut, kunci utama kesuksesan metode BPR ialah teknologi informasi. Pemahaman yang baik mengenai teknologi informasi membantu perusahaan merancang ulang grand design bisnisnya antara lain, menganalisis struktur di perusahaan, mengukur kinerja proses, mengimplementasikan dan mengoperasikan proses baru, serta memudahkan komunikasi antarkaryawan.

Peneliti melakukan pemberdayaan ini dengan bantuan prinsip rebranding atau BPR. Rebranding menjadi penting sebab produk usaha milik PP Nurul Haromain tidak mampu bersaing di pasar. Maka dari itu, grand design bisnis tersebut mengalami evaluasi dari berbagai orang yang ahli di bidangnya, seperti misalnya keorganisasian, sistem produksi, sistem pemasaran, hingga sistem pemasaran produk terebut.

\section{Manajemen Pengelolaan Sumber Daya Manusia}

Melalui buku yang berjudul "Fundamental of Human Resource Management" menjelaskan bahwa

13 Ibid. 
manajemen sumber daya manusia (SDM) telah mengalami evolusi dan perkembangan selama satu abad terakhir. ${ }^{14}$ Dalam tataran disiplin ilmu, berbagai macam teori tercipta melalui proses trial and error. Sedangkan dalam tataran praktiknya, telah banyak organisasi yang berusaha melakukan manajemen SDMnya dengan melihat perubahan lingkungan sekitar. Akibatnya, banyak sekali rumusan atau strategi yang lahir dari ranah teoritis dan praktis mengenai manajemen SDM.

Sebuah teori yang fasih digunakan banyak organisasi di era sekarang ialah teori Human Capital yang dicetuskan Becker ${ }^{15}$. Teori ini menjelaskan bagaimana sebuah organisasi memandang SDM sama seperti aset yang dimiliki. Untuk menjaga sumber daya manusianya, organisasi menginvestasikan dana yang tidak sedikit pada SDM. Becker percaya pelatihan dan pengembangan SDM yang dimiliki merupakan 'returnable investments'.

Sejumlah definisi mengenai Manajemen SDM dicetuskan oleh banyak peneliti.Namun, satu pengertian yang terkemuka yakni

14 Josephat Itika Stephen, Fundamental of Human Resource Management(Leiden: African Studies Centre, 2011), 1.

15 Ibid. 4. definisi yang dicetuskan oleh Storey, bahwa Manajemen SDM adalah "a distinctive approach to employment management which seek to achive competitive advantage through the strategic deployment of a highly committed and capable workforce, using an integrated array of cultural, structural, and personnel techniques" ${ }^{\text {" }}$.

Menurut Guest, manajemen SDM memiliki empat dimensi yang mencakup: (1) Komitmen, anggota mampu mengidentifikasi tujuan organisasi dan menyesuaikan diri supaya dapatmemberikontribusibagi organisasi; (2) Fleksibilitas, anggota beradaptasi dengan perubahan yang terjadi di dalam badan organisasi; (3) Kualitas, anggota dituntut untuk memberikan performa yang tinggi terhadap segala aktivitas organisasi; dan (4) Integrasi, mengolaborasikan strategi bisnis dengan kebutuhan SDM. ${ }^{17}$

Dalam menjalankan Manajemen SDM, ada peran penting yang dipegang oleh praktisi manajemen $\mathrm{SDM}^{18}$. Seorang praktisi yang profesional dalam memanajemen

\section{Ibid. 12.}

17 Adenidi A Anthonia \& Osibanjo A Omotayo, Human Resource Management: Theory \& Practice(Lagos: Punmark Nigeria Limited, 2012), 6 .

18 Anthonia, loc. cit, 8. 
SDM dapat membantu efektvitas dan efisiensi organisasi ketika beraktivitas. Praktisi dituntut untuk bisa proaktif terlibat dalam perumusan kebijakan organisasi dan memiliki pandangan yang visioner terkait dengan pengelolaan SDM.

Dari dua buku di atas yang dijadikan referensi terhadap manajemen SDM memiliki implikasi yang besar dalam penelitian ini. Buku yang ditulis Itika (2011) menjadi panduan umum mengenai perkembangan strategi manajemen SDM yang telah berangsung sekian lama. Ada banyak sekali teori yang bertahan hingga sekarang dan masih relevan untuk digunakan, khususnya Human Capital Theory yang menjadi acuan utama manajemen SDM pada usaha Pondok Pesantre Nurul Haromain. Selain itu, pandangan betapa pentingnya seorang praktisi manajemen SDM dalam suatu organisasi. ${ }^{19}$ Meski begitu, tidak ada penjelasan spesifik bagi organisasi/ perusahaan kecil yang memiliki SDM dan dana yang amat terbatas untuk menempatkan seorang praktisi profesional. Walaupun sebenarnya ada konsep umum yang dapat dijadikan patokan terhadap penelitian ini, terutama terkait dengan dimensi manajemen SDM.

19 Antonia, op. cit

\section{E. Participatory Action Research}

Penelitian ini menggunakan metodologi kualitatif melalui Participatory Action Research(PAR). Penelitian kualitatif mengelaborasikan metode dan teknik untuk mengamati, mendokumentasikan, menganalisis dan menafsirkan karakteristik, pola, atribut dan makna atas fenomena yang diteliti ${ }^{20}$ Tujuan metodologi kualitatif dilakukan dalam rangka menggambarkan dan memahami realitas sosial daripada bertujuan melakukan kontrol dan prediksi ${ }^{21}$. Sementara desain penelitian PAR menjadi bagian dari metodologi kualitatif.

Action Research sendiri merupakan sebuah desain penelitian yang di dalamnya terdapat rangkaian tindakan yang sistematis untuk menyelesaikan persoalan tertentu. ${ }^{22}$ Pengembangan dari Action Research menjadi PAR lebih menekankan pada aspek partisipasi yaang melibatkan peneliti dan para peserta (subjek penelitian) itu sendiri. PAR

20 Cathy MacDonald, Understanding Participatory Action Research: A Qualitative Research Methodology Option (Canadian Journal of Action Research, 13 vol 2, 2012), 34.

21 Ibid.

22 Bruce L Berg, Qualitative Research Methods for the Social Sciences.(New York: Pearson, 2004), 194. 
sebagai bagian dari Action Research menekankan aktivitas pengumpulan dan analisis data secara sistematis yang bertujuan untuk mengambil tindakandan melakukan perubahan melalui pemberdayaan pengetahuan yang bersifat praktis. ${ }^{23}$

PAR merujuk pada prosedur Action Research, mengarah pada empat langkah utama, meliputi mengidentifikasi persoalan penelitian,mengumpulkaninformasi untuk mengatasi persoalan, menganalisis dan mengintepretasi informasi dan menyampaikan hasil kepada partisipan. ${ }^{24}$ Lebih lanjut Kelly memberikan langkahlangkah teknis dalam melakukan PAR, antara lain: (1) Langkah awal (penilaian komunitas sebagai dasar tindakan, menemukan mitra komunitas, mempertimbangkan sumber daya yang tersedia untuk mengimplementasi program PAR dan pertimbangan etis); (2) Siklus perencanaan; (3) Tindakan; dan (4) Evaluasiataupeninjauan. Datautama dari desain penelitian PAR diperoleh dari focus group discussion, obervasi partisipatoris dan wawancara. ${ }^{25}$

23 A. Gillis \& $\quad$ W. Jackson,
Research methods for nurses: Methods and
interpretation(Philadelphia: $\quad$ F.A. Davis
Company, 2002), 264.
24 Berg, loc. cit, 198.
25 MacDonald, op. cit. 41.

Fokus penelitian ini adalah mengidentifikasi persoalan yang terdapat di PP Nurul Haromain berkaitan dengan bidang kewirausahaan, untuk selanjutnya dapat diformulasikan startegi mengatasi persoalan tersebut dengan menggali potensi yang ada didukung dengan pemberdayaan bagi pengelola usaha tersebut. Melalui desain penelitian ini selanjutnya dilakukan analisis data menggunakan model interaktif melalui tahapan kondensasi data, penyajian data dan penarikan simpulan atau verifikasi ${ }^{26}$. Oleh karena itu, berdasarkan desain penelitian ini dapat mencapai tujuan akhir dari PAR yakni melakukan perubahan sosial. ${ }^{27}$

\section{F. Hasil Diskusi}

Pondok Pesantren Nurul Haromain atau PP Nurul Haromain menjadi salah satu model pesantren yangtelahmengadopsiunsurmodern dalam aktivitas kepesantrenannya. Pondok pesantren ini tidak hanya memberikan ilmu agama ansich, namun juga terdapat aktivitas kewirausahaan yang dikelola di dalamnya. Sejumlah aktivitas

26 Matthew B. Miles, Michael A. Huberman \& Johny Saldana. Qualitative Data Analysis A Methods Sourcebook (Edition 3) (United States of America: SAGE Publications, Inc, 2014)

27 MacDonald, op cit, 46. 
kewirausahaan tersebut diantaranya: koperasi, mini market atau swalayan, kantin dan air mineral. Pengembangan yang dilakukan oleh pesantren sebagai wujud kreativitas dalam merespon perubahan. Pesantren berusaha tidak terbawa arus atau menjadi objek perubahan, tetapi mampu membuat arus alternatif menjadi subjek atau agen perubahan. Pengembangan berbasis kewirausahaan yang dilakukan oleh pesantren, sangat relevan dengan pandangan Tan yang menyatakan bahwa spirit kewirausahaan penting dimiliki pesantren sebagai bentuk independensi untuk bertahan (survive) dengan tidak bergantung pada pemerintah. ${ }^{28}$

\section{Langkah-langkah}

untuk

melakukan perubahan sosial diawali dengan mengetahui kondisi komunitas atau dalam hal ini PP Nurul Haromain sebagai upaya melakukan penilaian sebagai dasar merumuskan tindakan. Melalui aktivitas Forum Group Discussion (FGD), observasi partisipatoris, survei dan wawancara, diketahui bahwa aktivitas kewirausahaan di PP Nurul Haromain bernaung di bawah Ekonomi Mahad (BEM).

28 Charlene Tan. Islamic Education and Indoctrination: The Case in Indoesia(New York: Routledge, 2011)
BEM sendiri sementara ini masih belum berdiri sendiri sebagai sebuah divisi melainkan menginduk di bawah bidang keuangan (bendahara umum). Keterbatasan sumber daya manusia menjadi kendala yang dihadapi dalam melakukan pengelolaan secara menyeluruh. Untuk melakukan pengelolaan aktivitas usaha air mineral, hanya ada tiga orang yang bekerja secara simultan. Pembagian kerja hanya dilakukan dengan kesepakatankesepakatan teknis dan bersifat emosional atau kedekatan personal. Menurut Krame \&Hess, pengelolaan profesionalitas (maintaining professionalism) merupakan inti dari manajemen. ${ }^{29}$ Kemampuan manajerial diperlukan untuk mendukung aktivitas kewirausahaan agar dapat berjalan dengan optimal.

Aktivitas kewirausahaan PP Nurul Haromain yang menjadi fokus penelitian ini adalah usaha air minum Q-Zulal. Melalui hasil observasi dan FGD dengan pihak pengelola air minum Q-Zulal, secara lebih rinci kondisi pengelolaan usaha ini belum berjalan dengan efektif. Dalam aspek produk, masih

29 Michael W. Kramer \& Jon A. Hess. Communication Rules for the Display of Emotions in Organizational Settings.(Management Communication Quarterly,2002) 
terkendala terkait legalitas produk. Produk air minum Q-Zulal masih belum memiliki lisensi sebagai standar nasional produk. Sementara dari aspek kapasitas produksi juga masih terbatas. PP Nurul Haromain mempunyai dua tandon dengan masing-masing tandon memiliki kapasitas 1100 liter.

Pesantren hanya memproduksi air Q-Zulal berkemasan galon dan botol saja dan belum dalam kemasan gelas. Masalah lain dari produk Q-Zulal adalah produk ini tidak bisa bersaing secara harga dengan produk-produk air minum lain di pasaran. Hal ini karena biaya produksi yang masih besar, akibat masih membeli bahan produksi yang terbatas dan cenderung membuat harga lebih mahal. Padahal dalam konteks kualitas air, air minum Q-Zulal bukanlah air mineral biasa melainkan air hexagonal.

Pihak pondok menerangkan bahwa usaha air minum Q-Zulal sifatnya sebagai usaha yang regeneratif. Mengingat pengelola yang ada selalu berganti dari waktu ke waktu sesuai dengan tugas yang diberikan oleh pondok. Saat pondok menugaskan di tempat lain, maka sebagai santri akan mengikuti sesuai dengan amanah yang diberikan. Oleh karena itu, pengelola sering diisi orang-orang baru sesuai dengan sumber daya yang tersedia.

Pihak Pondok PP Nurul Haromain melalui pengelola Q-Zulal memang menyampaikan belum memiliki grand design terkait usaha yaang sedang dikelolanya. Pihak pengelola, menekankan terbatas pada berjalannya usaha, belum pada manajemen pengelolaan yang sistematis. Produksi air Q-Zulal sementara secara ketersediaan air tidak ada masalah meski harus dibagi penggunaannya dengan operasional pondok secara internal. Ketercukupan ketersediaan air tersebut seiring dengan daya jual yang juga terbatas.

Dalam konteks filosofi Q-Zulal sendiri sebenarnya sangat mendalam, karena nama ini langsung diberikan oleh pengasuh pondok yang menjadi guru utama di PP Nurul Haromain yakni KH Ihya Ulumuddin. Awalnya, namanya adalah Zulal saja yang berarti bening atau sangat jernih, kemudian dalam rangka untuk pemasaran, pihak pengelola menambahkan kata $\mathrm{Q}$ yang merujuk ke quality. Melalui produk ini, berharap menekankan kualitas produk yang baik dengan menonjolkan kejernihan air. Beberapa testimoni dari masyarakat yang masuk ke pihak pengelola dari 
aspek produk sebenarnya cukup positif.

Permasalahan lain yang dihadapi pengelola dalam melakukan manajemen usaha ini adalah belum bisa total mengelola usaha karena harus dibagi dengan aktivitasaktivitas pondok yang lain. Namun, pengelola tetap menekankan bahwa aktivitas pondok tersebut memang di satu sisi tidak bisa membuat kerja secara total khusus mengelola usaha air, namun justru aktivitas lain di luar usaha dalam hal ini mengaji menjadi ruh dari sistem kewirausahaan ini. Gaya kewirausahaan pondok selain melakukan ikhtiar ekonomi tidak lupa yang utama adalah mendekatkan diri kepada Allah SWT agar mendapatkan barokah dari setiap usaha yang dilakukannya.

Minimnya sumber daya pengelola air minum Q-Zulal membuat ketidakefisiensian pengerjaan. Jumlah pegawai terdiri dari tiga orang dengan jobdesk sesuai struktural adalah koordinator, produksi, dan pemasaran, namun jobdesk tersebut tidak beroperasi semestinya. Pada kesehariannya tiga orang pegawai bahu-membahu dan terkesan cukup tumpang tindih dengan mengerjakan pra-produksi, produksi dan pasca produksi.
Berdasarkan hasil identifikasi persoalan dan potensikewirausahaan yang terdapat di PP Nurul Haromain, peneliti membuat perencanaan untuk mengatasi persoalan tersebut. Untuk membuat perencanaan sebagai solusi, peneliti melibatkan partisipan. Melalui FGD, peneliti menyampaikan sejumlah persoalan kepada para pengelola usaha di pesantren, sehingga dapat membangun kesadaran untuk membuat solusi secara kolektif. Dari sisi peneliti memberikan pandangan atas penilaian yang telah dilakukan, sementara pihak partisipan diberikan kesempatan untuk menyampaikan persoalan yang dihadapi dan kebutuhan yang diperlukan dalam rangka mengembangkan usaha yang telah dikelola pesantren. Melalui aktivitas ini diperoleh dua persoalan utama, yakni (1) keterbatasan kemampuan manajerial pengelola usaha; (2) pengelolaan produk yang belum terstandar. Persoalan utama tersebut menjadi dasar merumuskan skema perencanaan berupa workshop dan pendampingan terkait manajemen produksi dan manajemen pengelolaan internal.

Setelah membuat perencanaan dengan mempertimbangkan persoalan yang dihadapi dan potensi yang dimiliki, peneliti 


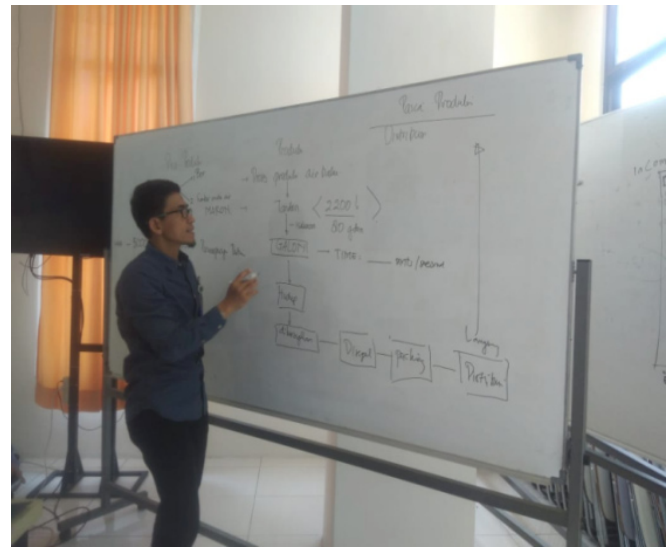

menindaklanjuti dengan melakukan implementasi sebagai sebuah program pemberdayaan bagi para pengelola usaha air Q-Zulal. Melalui FGD, workshop dan pendampingan dilakukan untuk memberikan pelatihan keterampilan agar dapat meningkatkan kemampuan manajerial agar proses pengelolaan usaha yang telah dijalankan oleh pesantren dapat berjalan secara optimal.

Melalui workshop ini, pihak pengelola Q-Zulal diberikan dua materiutama, meliputi(1)manjamen produksi dan (2) manajemen sumber daya pengelola. Dalam materi pertama, pihak pesantren diajak untuk mengidentifikasi prosesproses produksi agar dapat berjalan efektif dan efisien. Identifikasi ini mengarah pada tiga aspek, mulai dari pra-produksi, produksi sampai pasca produksi.

Peneliti memberikan paparan dengan membuat alur proses produksi agar dapat dengan mudah dipahami oleh pengelola Q-Zulal. Workshop ini berlangsung secara partisipatif, mengingat materi yang diberikan tidak hanya bersifat satu arah melainkan justru melibatkan keaktifan peserta workshop yang dalam hal ini merupakan para pengelola usaha Q-Zulal itu sendiri. Partisipasi tersebut dilakukan untuk mengetahui sejauhmana pengelolaan yang sudah dijalankan oleh pondok dan upaya evaluasi yang dapatdilakukanuntukmeningkatkan efektivitas pengelolaan yang ada.

Melalui materi pertama ini menghasilkan rancangan Standar Operasional Prosedur (SOP). SOP dimungkinkan dapat membantu proses manajerial aktivitas pengelolaan usaha pondok, baik berkaitan dengan proses produksinya di satu sisi maupun pembagian tugas di antara sumber daya yang tersedia. SOP diarahkan untuk dapat membantu proses dari pra produksi sampai tahapan produksi dan pasca produksi.

Jika workshop pada materi pertama telah menghasilkan SOP, materikedualebih menekankan pada pengelolaan sumber daya pengelola secara internal. Menindaklanjuti materi pertama, materi kedua menghasilkan alur pengelolaan 


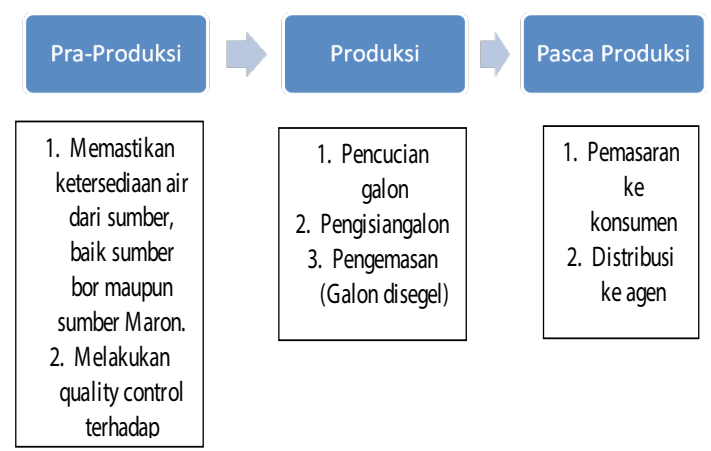

internal yang dapat menunjang pelaksanaan SOP yang telah didesain sebelumnya. Berikut ini sebagai hasil proses pengorganisasian sumber daya pengelola Q-Zulal.

Materi kedua didesain agar pihak pengelolaQ-Zulaldapatlebihoptimal dalam melakukan manajemen internal baik selama proses produksi sampai pasca produksi. Pengelolaan tidak bisa hanya menekankan pada

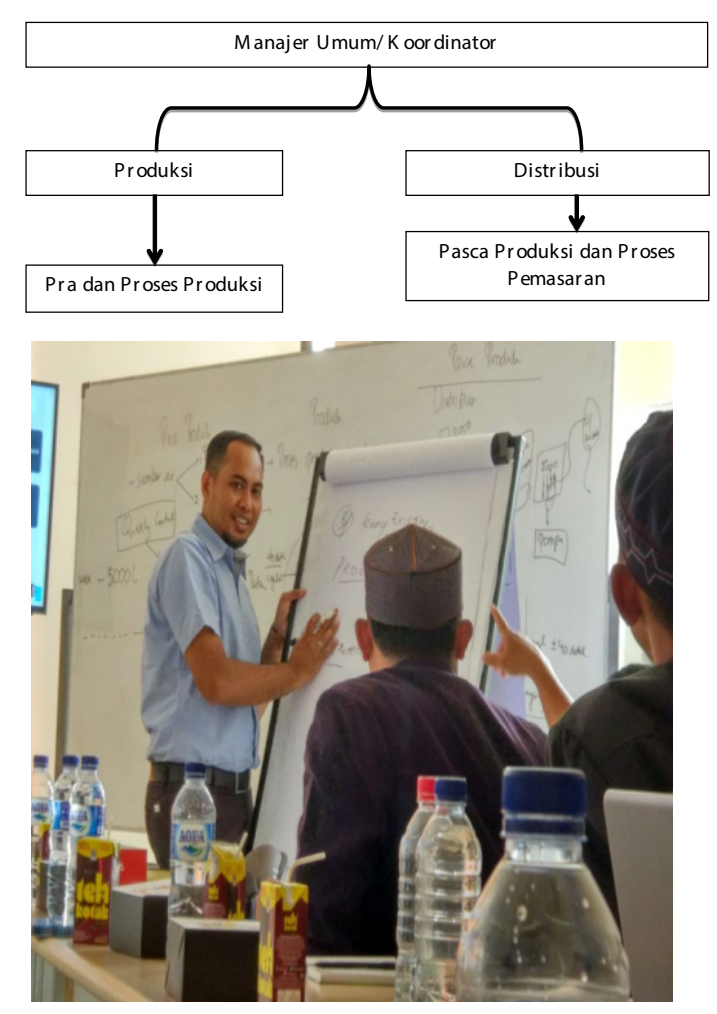

satu pihak, sehingga memungkinkan terjadinya overjob, sementara pihak yang lain lessjob. Tata kelola ini memberikan formula agar masingmasing divisi dapat optimal sesuai dengan tupoksinya.

\section{Implementasi program} pemberdayaan ini menghasilkan dua luaran utama yakni SOP sebagai dasar pengaturan proses produksi dan strukturturisasi sumber daya pengelola sebagai upaya meningkatkan aspek pengelolaan manajerial yang baik. Secara umum, dua luaran tersebut menjadi sarana untuk mengembangkan kewirausahaan di PP Nurul Haromain terutama dalam bidang usaha air Q-Zulal. Praktik usaha bukan hanya sebagai keterampilan sampingan yang tidak dikelola secara terpadu dan profesional, melainkan juga menjadi ciri khas pesantren dalam mewujudkan santri-santri yang berjiwa entrepreneur.Berikut ini adalah skema Participation Action Researh atas upaya pemberdayaan masyarakat sipil di PP Nurul Haromain. 


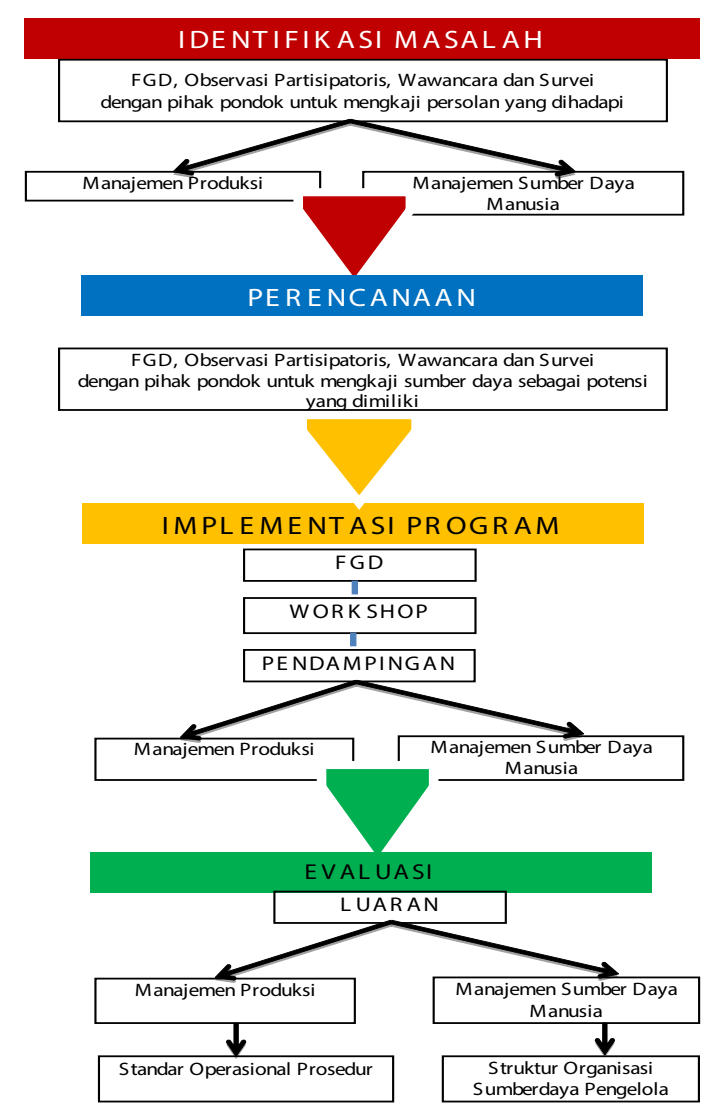

\section{G. Penutup}

Berdasarkan hasil paparan data dan implementasi program Doktor Mengabdi yang telah dilakukan sebelumnya, menggambarkan bahwa temuan di lapangan terkait manajemen internal produksi air Q-Zulal masih belum optimal. Minimnya pengorganisasian antar sumber daya manusia yang tersedia ditambah dengan belum memadainya manajemen produksi menjadikendalautamayangdihadapi oleh pengelola Q-Zulal. Melalui program FGD, workshop dan pendampingan, diperoleh sejumlah output di antaranya rancangan
Standar Operasional Prosedur (SOP) dan manajerial tata kelola sumber daya manusia yang terstruktur.

Skema pemberdayaan ini sebagai bentuk komunikasi untuk perubahan sosial di lingkungan pengelola air Q-Zulal di PP Nurul Haromain. Desain penelitian sekaligus pemberdayaan ini dapat mengubah sikap, perilaku dan mampu memberikan pengetahuan khususnya spek manajerial bagi partisipan. Adapun saran yang perlu dilakukan dalam rangka meningkatkan pengelolaan usaha ini antara lain, pihak pondok dapat meningkatkan manajemen internal berkaitan dengan pembagian jobdesk dan alur proses produksi. Pihak pondok dapat menambah jumlah sumber daya manusia pengelola dalam konteks produksi dan melakukan quality control dalam setiap aktivitas produksinya. 


\section{Daftar Pustaka}

A. Gillis \& W. Jackson, Research methods for nurses: Methods and interpretation (Philadelphia: F.A. Davis Company, 2002)

Adenidi A Anthonia \& Osibanjo A Omotayo, Human Resource Management: Theory \& Practice (Lagos: Punmark Nigeria Limited, 2012)

Bruce L Berg, Qualitative Research Methods for the Social Sciences. (New York: Pearson, 2004)

Cathy MacDonald, Understanding Participatory Action Research: A Qualitative Research Methodology Option (Canadian Journal of Action Research, 13 vol 2, 2012)

Charlene Tan. Islamic Education and Indoctrination: The Case in Indoesia (New York: Routledge, 2011)

Godfrey C. Onwubolu dkk,Production Management Issues in Developing Nations.(Production Planning and Control, Vol10 (2), 1999)

Josephat Itika Stephen, Fundamental of Human Resource Management(Leiden: African Studies Centre, 2011)
Josephus Primus, "Apa jadinya Indonesia Tanpa Wirausaha?", diakses dari https:// edukasi.kompas.com / read/2018/03/23/08450051/ apa-jadinya-indonesia-tanpawirausaha-, pada tanggal 13 November 2018 pukul 20.00.

Majid Tehranian, Communication and Theories of Social Change: $A$ CommunitarianPerspective(Asian Journal of Communication, 2009)

Marwan M. Kraidy, Social Change and the Media(Encyclopedia of communication andinformation, Vol 3 (1), 2002)

Matthew B. Miles, Michael A. Huberman \& Johny Saldana. Qualitative Data Analysis A Methods Sourcebook (Edition 3) (United States of America: SAGE Publications, Inc, 2014)

Michael W. Kramer \& Jon A. Hess. Communication Rules for the Display of Emotions in Organizational Settings. (Management Communication Quarterly,2002)

Naqib Daneshjo, Porduction Management Systems(Transfer inovácit, Vol28, 2013) 


$\begin{aligned} & \text { Nedelljko Stefanić., Ozana } \\ & \text { Kriżan., \&Ivo Cala,Models }\end{aligned}$
$\begin{aligned} & \text { and Methods of Production } \\ & \text { Management(Strojarstvo, Vol 3, }\end{aligned}$
$\begin{aligned} & \text { Rradip Ninan TheoryCount(Nordicom } \\ & \text { 2008) }\end{aligned}$
$\begin{aligned} & \text { injustice: ICTS \& Social Change } \\ & \text { Pradip Queensland: The University }\end{aligned}$
$\begin{aligned} & \text { Communicationfor Social Change, } \\ & \text { of Queensland Australia, 2013) }\end{aligned}$

